Research Article

\title{
The Effect of Transactional Leadership and Organizational Culture to Employee Performance through Motivation of Employment
}

\author{
${ }^{1}$ Rudi Firmansah, ${ }^{2}$ Edy Supriyadi, ${ }^{3}$ Wirawan \\ ${ }^{1}$ PT Marta Teknik Tunggal \\ ${ }^{2,3}$ Graduate School of Universitas PAncasila
}

\begin{abstract}
Transactional Leadership, Organizational Culture and Work Motivation are useful in contributing to improving Employee Performance. This study aims to determine the Influence of Transactional Leadership, Organizational Culture and Work Motivation on Employee Performance at Marta Teknik Tunggal Cop. This research was conducted in October 2017 until February 2018 with the number of respondents 125 people. To achieve the research objectives, the researcher uses quantitative method with collecting data from library and field research, through observation, interview and questionnaire, while SEM (Structural Equation Modeling) data analysis method using PLS software version 2.0 (Patrial Least Square). Result obtained (1) There is Influence of Transactional Leadership to Work Motivation (2) There is Influence of Organization Culture to Work Motivation (3) There is no influence of Transactional Leadership Style to Employee Performance (4) There is Influence of Transactional Leadership Style to Employee Performance (5) There is Influence Transactional Leadership Style on Employee Performance.
\end{abstract}

Key words: Transactional Leadership, Organizational Culture, Work Motivation and Employee Performance.

\section{Introduction}

Entering the era of globalization, the absolute necessity of a strong human resource can not be denied in the face of this new era, organizations or companies will face an increasingly complex form of competition with variations, intensities and scopes that may never have been experienced before, a tough person, who is able to adapt quickly to any changes that occur, who are able to work in new ways through their skills and duties.

The most important resource for the organization is the human resources, the people who give their energy, talents, ideas and creativity to the organization. Therefore, the performance of the organization whether it is a business organization, nonprofit, or government organization, not apart from individual performance. In this connection factors that can be used to improve employee performance one of them is leadership, organizational culture, and work motivation.

Employee performance is necessary to achieve organizational goals. It is closely related to several factors that influence it, such as leadership, organizational culture, and work motivation, because without good leadership, organizational culture, and employee motivation will be difficult to achieve the expected performance of employees in the organization.

The problem faced by PT Marta Teknik Tunggal, currently is not the realization of the timely project completion which is presumably caused by the decrease of productivity which continuously so that the target is not reached. This is evident from the project report data of the project implementation period exceeds the time limit set so that the production target is not achieved. Not achieving this production target is assumed because employee work discipline is less than optimal, low work ethic shown by employees, employees who look relax during working hours, high employee absenteeism, low job satisfaction level, delayed execution of office duties, employees sometimes out office hours during office hours, free working clothes, lack of work motivation from employees of the company, employees often only do what is ordered to him, so that when something happens beyond the command of his superiors, the employee becomes silent, and do nothing, tend to slow down work.

Based on the above problem identification then in this writing, the author makes four dominant variables are:

1. Employee Performance (Y)

Performance is the result of work that can be achieved by a person or group of persons within an organization, in accordance with their respective powers and responsibilities in an effort to achieve the objectives of the organization concerned legally, unlawfully and in accordance with morals and ethics.

2. Work motivation (Z)

Motivation of work is a growing impulse in a person, both coming from within and outside himself to do a job with high spirits using all the skills and skills it has to gain the results of work to achieve satisfaction in accordance with his wishes.

3. Transactional Leadership (X1)

Leadership is the ability of a leader to control, lead, influence the thoughts, feelings or behavior of others, to achieve predetermined goals.

4. Organizational Culture (X2)

Organizational culture is a shared system of meaning shared by members who differentiate the organization from other 
organizations

Problem formulation can be made based on problem identification and problem restriction as follows:

1. Does Transactional Leadership Affect Employee Performance?

2. Does Organizational Culture Affect Employee Performance?

3. Does Transactional Leadership Have an Effect on Work Motivation?

4. Does Organizational Culture Influence on Work Motivation?

5. Does Work Motivation Affect Employee Performance?

6. How much direct, indirect and total influence between Transactional Leadership, Organizational Culture on Employee Performance through Work Motivation.

\section{Literature Review}

\section{Employee Performance}

Performance is derived from the word job performance or actual performance which means work performance or achievement actually achieved by someone. Understanding performance is the work of quality and quantity achieved by an employee in performing its functions in accordance with the responsibilities given to it. (Mangkunegara, 2013).

Performance by Wirawan $(2013,732)$ is the output generated by the functions or dimensions of work or profession performed by the employee within a certain time.

\section{Work motivation}

Wilson Build (2012, 312) The motivation comes from the word motif which means encouragement. Thus motivation means a condition that encourages or becomes the cause of a person doing an act or activity, which takes place consciously. Motivation can be defined as an action to influence others to behave on a regular basis. Motivation is a task for managers to influence others (employees) within a company. From the definition of motivation above, it can be seen that there are three things that include among others effort, organizational goals and needs.

\section{Transactional Leadership}

Leadership is one of the tasks of managers in achieving organizational goals. Therefore, leadership is one of the functions of management. In the book Wilson Bangun (2015) many opinions put forward by some experts about leadership that has its own understanding among others, Koontz defines leadership as the influence of art or the process of influencing people so that they will strive in achieving group goals with the will and enthusiasm.

According to Bass in Robbins \& Judge (2009: 90) transactional leadership style is a leadership model in which leaders combine or motivate their followers in the direction of enforced goals by clarifying roles and task demands. In Robbins \& Coulter (2012: 497), a leader with a transactional leadership style is a leader who guides and motivates followers toward the goals set by rewarding their productivity.

\section{Organizational culture}

According to experts in the book of wisdom (2015) Andrew Brown (1998) defines Organizational Culture as "Pattern of beliefs, velues, and learns of coping with experience that has developed in the course of an organization's history, and wich tend to be manifested in its material aggrements and in the behaviors of its members "which means organizational culture is a pattern of beliefs, values and ways learned face experiences that have been developed throughout the organization's history that manifests in the organization's material and behavioral settings. Definition Organizational culture is the norm, values, assumptions, philosophy of an organization developed by an organizational leader and applied in the organizational behavior of members of that organization. In general, organizational culture is defined as a vision, mission, strategic objectives and strategic values. Organizational culture is taught to members and supervised its implementation systematically (Wirawan, 2007).

\section{Research Methods}

\section{Population}

According to Wirawan (2015: 735) The study population is a collection of individual objects people who became the focus of statistical research. In this case the research is meant by individuals are employees or employees and managers who work for companies or organizations.

According to Edy Supriyadi (2014: 17) population is a generalization area in the form of subjects or objects under study to be studied and taken conclusions.

In this study the population used is employees at PT Marta Teknik Tungga. The number of respondents as many as 216 employees comes from several levels of rank.

\section{Sample}

According Sugiyono (2012: 81) The sample is part of the number and characteristics possessed by the population. When the population is large, and researchers are unlikely to study all existing populations, for example due to limited funds, manpower and time, the researchers can use samples taken from that population.

According to Edi Supriyadi (2014: 17) The sample is partly or acts as a representative of the population so that the results of successful research obtained from the sample can be generalized to the population.

In this research, sampling is done by taking respondents with permanent employees status as many as 125 people.

\section{Data collection}

Data collection will deal with the precision of the means used to collect data. In this study using data collection techniques as follows:

\section{Questionnaire}

The questionnaire is an instrument to capture the data required in the study which contains a number of statements in detail, equipped with instructions how to fill it with reference to the 
indicator of each research variable that has been determined.

2. Observation and Interview

Conducted observations and interviews to obtain additional data and information about the variables studied.

\section{Library Studies}

This literary study includes a study of secondary data used as a basis for the preparation of the flow of thought or theoretical framework derived from documentation, books, journals and scientific papers.

\section{Literature Studies}

In collecting data through this documentation study the researcher seeks to obtain secondary data, whether derived from legislation, books, guidelines or guidelines on the implementation of work, reports and the like with relevance to the subject.

Operational Variables consist of Dependent Employee Performance (Y) variable, Intermediary Motivation (Z), and independent variable are Transactional Leadership (X1), Organization Culture (X2)

\section{SEM Statistical Method ("Structural Equation Modeling")}

In its current development the path analysis is expanded and deepened into the form of "Structural Equation Modeling" analysis known as SEM. according to Supriyadi (2013: 101) Structural Equation Modeling (SEM) is a statistical technique used to analyze the relationship between latent variables with observed variables as indicator, the relationship between latent variables and measurement error. SEM has the ability to estimate the relationship between multiple relationship variables. Relationships are formed in a structural model (the relationship between latent dependent and independent variables). SEM is also able to illustrate the pattern of relationships between latent constants and manifest variables. SEM analysis is done because it can translate relationships of social variables that generally are not directly measurable.

The SEM stage is as follows: (1) Development of theoretical model (2) Development of Line Diagram (3) Conversion of Line Diagram into Structural Equation (4) Selecting Input Matrix and Estimation of built model (5) Assessing problem Identification (6) Interpretation and Modified Models

\section{Hypothesis}

1. Transactional Leadership has positive effect on Work Motivation

2. Organizational culture has a positive effect on Work Motivation

3. Transactional Leadership has appositive effect on Employee Performance

4. Organizational Culture has a positive effect on Employee Performance

5. Work Motivation has a positive effect on Employee Performance

\section{Hypothesis testing}

Hypothesis test is used to test the effect of exogenous variables $(\mathrm{x})$ on endogenous variables (y) by looking at $\mathrm{t}$ - values on each path. T-calculated values are obtained from data processing using a procedure called bootstrapping, Smart PLS version 2.0 can generate t-Statistics of Path Coefficients (Inner Model) and T-Statistics of Outer Loadings to test the significance of the structural model and measurement model. By using two-sided t-tables, a significance level of 5\%, it is known that t-tables of 1.96 path coefficients will be significant if t-statistics are larger than t-tables and are said to be insignificant if $\mathrm{t}$-statistics are smaller than $\mathrm{t}$ - table.

Table 1. T-Statistics of Path Coefficients (Inner Model)

\begin{tabular}{|c|c|c|c|c|c|}
\hline Variable & $\begin{array}{l}\text { Original } \\
\text { Sample } \\
\text { (O) }\end{array}$ & $\begin{array}{l}\text { Sample } \\
\text { Mean } \\
(\mathrm{M})\end{array}$ & $\begin{array}{l}\text { Standard } \\
\text { Deviation } \\
\text { (STDEV) }\end{array}$ & $\begin{array}{l}\text { Standard } \\
\text { Error } \\
\text { (STERR) }\end{array}$ & $\begin{array}{lr}\text { T } & \text { Statistics } \\
(|\mathrm{O} / \mathrm{STERR}|)\end{array}$ \\
\hline $\begin{array}{ll}\mathrm{BO} & \rightarrow \\
\mathrm{KK} & \end{array}$ & 0.314109 & 0.313436 & 0.110872 & 0.110872 & 2.833069 \\
\hline $\begin{array}{ll}\mathrm{BO} & \rightarrow \\
\mathrm{MK} & \end{array}$ & 0.223403 & 0.214010 & 0.028778 & 0.028778 & 7.762909 \\
\hline $\begin{array}{ll}\mathrm{KT} & -> \\
\mathrm{KK} & \end{array}$ & $\begin{array}{l}- \\
0.306916\end{array}$ & $\begin{array}{l}- \\
0.278154\end{array}$ & 0.246699 & 0.246699 & 1.244090 \\
\hline $\begin{array}{ll}\mathrm{KT} & -> \\
\mathrm{MK} & \end{array}$ & 0.820201 & 0.828128 & 0.022746 & 0.022746 & 36.058887 \\
\hline $\begin{array}{ll}\mathrm{MK} & \rightarrow \\
\mathrm{KK} & \end{array}$ & 0.882802 & 0.854175 & 0.293614 & 0.293614 & 3.006670 \\
\hline
\end{tabular}

T-statistic smaller than T-table that is equal to 1,96 so it can be said not significant there is one relation of variable that is not significant, while t-statistic bigger than t-table that is equal to 1,96 hence can be said coefficient of path model of both statistically significant

The T-statistics of the measurement model larger than 1.96 can be said to be all valid. To find out the results of $t-$ calculated value obtained from the data processing using SmartPLS version 2.0 can be seen as shown below:

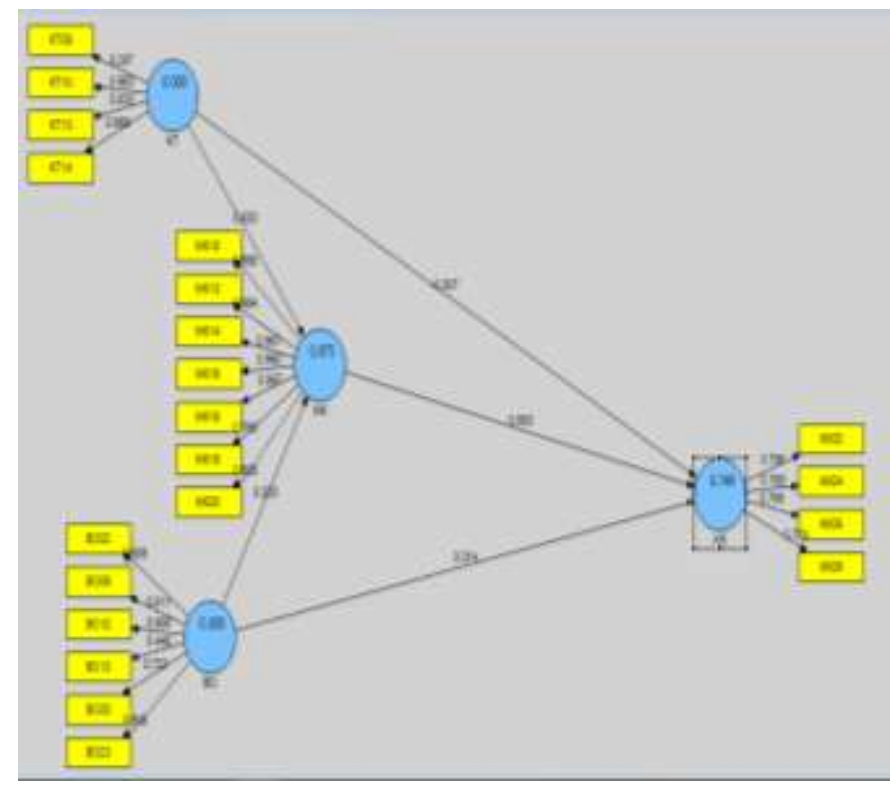

Figure 1. Complete Model of SEM 
Source: Output from PLS Bootstrapping Data Processing.

Based on the output of data processing PLS Bootstrapping can be seen the value of t-statistics combined with the output of data processing PLS Algorithm so that the conclusion of the data processing concluded briefly shows the conclusion of hypothesis testing results from the above model.

Table 2. Path Coefficient and T-Statistic Value Between Variable

\begin{tabular}{|l|l|l|l|l|l|}
\hline $\begin{array}{l}\text { Variablel } \\
\text { Eksogen }\end{array}$ & Relationship & $\begin{array}{l}\text { Variable } \\
\text { Endogen }\end{array}$ & $\begin{array}{l}\text { Path } \\
\text { Coefifsien }\end{array}$ & T-Statistic & Decision \\
\hline KT & $\longrightarrow$ & MK & 0,820201 & 36,058887 & Signifikan \\
\hline BO & $\longrightarrow$ & MK & 0,223403 & 7,762909 & Signifikan \\
\hline KT & $\longrightarrow$ & KK & $-0,306916$ & 1,244090 & $\begin{array}{c}\text { Tidak } \\
\text { Signifikan }\end{array}$ \\
\hline BO & $\longrightarrow$ & KK & 0,314109 & 2,833069 & Signifikan \\
\hline MK & $\longrightarrow$ & KK & 0,882802 & 3,006670 & Signifikan \\
\hline
\end{tabular}

Hypothesis Testing Results

The T-Statistic score should be above 1.96, which indicates a significant level, in the hypothesis test to one t-statistical value of 36.058887 above 1.96 then significant between Transactional Leadership to Work Motivation. The second hypothesis of t-statistical value of 7.762909 above 1.96 then it is interpreted that the organizational culture variable to Work Motivation is significant. The third hypothesis t-statistic value of 1.244090 below the value of 1.96 it can be interpreted that the variable Transactional Leadership on Employee Performance is not Significant. Fourth hypothesis t-statistical value of 2.833069 above the value 1.96 it can be interpreted that the variable Transactional Leadership on Employee Performance significant. The value of t-statistics on the fifth hypothesis of 3.006670 above 1.96 it can be interpreted that the variable Transactional Leadership on Employee Performance is significant.

\section{Hypothesis Discussion}

1. There is influence of Transactional Leadership on Work Motivation.

This means that Transactional Leadership has a powerful influence on Work Motivation. This means that the relationship between Transactional Leadership to Work Motivation has a significant level, the first hypothesis accepted.

2. There is influence of Organization Culture on Work Motivation

The relationship between organizational culture to work motivation has a level of significance, it can be said that the variable of Organizational Culture on Job Motivation is very good, habits in giving direction, wage, and provide motivation to its employees, meaning Organizational Culture Influence Positive and significant to Work Motivation, second hypothesis be accepted.

3. No effect of Transactional Leadership on Employee
Performance.

4. There is influence of Organization Culture on Employee Performance.

This means that the relationship between Organizational Culture on Employee Performance has a level of significance, therefore it can be said that the fourth hypothesis proved, meaning Organizational Culture has a significant positive effect on Employee Performance. This means the fourth hypothesis is accepted.

5. There is influence of Work Motivation on Employee Performance.

Work Motivation gives a positive and significant influence on Employee Performance. Therefore it can be said that the fifth hypothesis is proved and accepted.

\section{Direct, Indirect and Total Effect}

Table 3. Direct, Indirect and Total Effect

\begin{tabular}{|l|l|l|l|}
\hline $\begin{array}{l}\text { Relationship } \\
\text { Between } \\
\text { Variables }\end{array}$ & Direct & $\begin{array}{l}\text { Indirect } \\
\text { Through } \\
\text { MK }\end{array}$ & Total \\
\hline $\begin{array}{l}\text { KT terhadap } \\
\text { MK }\end{array}$ & 0,8202 & & \\
\hline $\begin{array}{l}\text { BO terhadap } \\
\text { MK }\end{array}$ & 0,2234 & & \\
\hline $\begin{array}{l}\text { KT terhadap } \\
\text { KK }\end{array}$ & $-0,3069$ & 0,7240 & \\
\hline $\begin{array}{l}\text { BO terhadap } \\
\text { KK }\end{array}$ & 0,3141 & 0,1972 & 0,5113 \\
\hline $\begin{array}{l}\text { MK terhadap } \\
\text { KK }\end{array}$ & 0,8828 & & \\
\hline
\end{tabular}

The result of the analysis shows that the independent variable of Transactional Leadership has a direct effect on the Work Motivation with the coefficient value of 0.8202 . Likewise Organizational Cultural variables directly influence significantly to Work Motivation with coefficient value of 0.2234. Dependent variable Employee Performance is not directly influenced by Transactional Leadership with coefficient value -0.3069 and indirectly influenced through intervening variable that is Motivation Variables Work with total coefficient value 0.7240. Variable dependent Employee Performance influenced directly and indirectly by Organization Culture variable with total value 0,51113. The greatest coefficient value of variable intervening to the dependent variable is Job Motivation variable on Employee Performance is very influential with the value of 0.8828 .

\section{Conclusion and Recommendations}

\section{Conclusion}

Based on the results of research and discussion, it can be drawn some conclusions as follows:

1. Transactional leadership has a very strong and significant influence on Work Motivation. The transactional leadership 
style applied today is the most appropriate and excellent style to improve employee work motivation.

2. Transactional leadership has a very weak and insignificant influence on employee performance, meaning that the current transactional leadership style is influenced by other factors, namely through variable intervening variable work motivation. So the transactional leadership style will be very strong and significant on employee performance if the employee is in motivation.

3. Organizational Culture has a significant influence on Work Motivation means Organizational Culture which has been well established and can affect work motivation, even if improved better will make Employee Performance better. Organizational Culture on Employee Performance or through Work Motivation all have a strong and significant influence.

4. The greatest direct effect is on the variable of work motivation on employee performance, while the biggest indirect influence is on transactional leadership variable on employee performance through work motivation.

5. Identify the unanswered problem of project delay due to other factors not examined in this study, the temporary estimate could be due to natural or financial problems.

\section{Recommendation}

Based on the results of this study, some suggestions that can be given in this study are:

1. Transactional leadership style can be maintained is still good and relevant to the type of construction services business with a condition to improve employee performance should provide better work motivation than the existing today.

2. Organizational culture nowadays can also be maintained even can be improved because it can make Employee Performance on either through or not to Work Motivation, Organizational Culture either directly or indirectly can improve employee performance, if employee performance increase by itself increase company productivity.

3. The current motivation should be improved, for example by increasing incentives or year-end bonuses.

4. Further research is needed to determine the causes of project delays.

\section{Reffrences}

[1] AA. Anwar Prabu Mangkunegara. 2013. Manajemen Sumber Daya Manusia Perusahaan. Bandung. Remaja Rosdakarya.

[2] Bangun, Wilson. 2012. Manajemen Sumber Daya Manusia. Jakarta. Erlangga.

[3] Brown, Andrew. 1998. Organizational Culture. Second Edition. England. Pearson Education.

[4] Gozali, I. 2015. Aplikasi Analisis Multivariate dengan Program SPSS. Semarang. Universitas Diponegoro.

[5] Robbins, P. Stephen and Timothy A. Judge, 2009, Organizational Behavior, $13^{\text {th }}$ Edition, Pearson Education, Inc., Upper Saddle River, New Jersey, pp. 209-586.

[6] Robbins,Stephen P. and Coulter,Mary. 2012.
Management. New Jersey: Pearson Education, Inc.

[7] Supriyadi, Edi. 2014. SPSS+Amos. Jakarta: In Media

[8] Sugiyono. 2012. Metode Penelitian Kuantitatif Kualitatif dan R\&D. Bandung: Alfabeta.

[9] Sondang P. Siagian, 2015. Manajemen Sumber Daya Manusia Jakarta .Bumi Aksara.

[10] Wirawan, 2007. Budaya dan Iklim Organisasi. Jakarta. Salemba Empat

[11]---------2013. Kepemimpinan, Teori, Psikologi, Perilaku Organisasi, Aplikasi dan Penelitian. Jakarta. PT. Raja Grafindo Persada.

[12]-----------. 2015. Manajemen Sumber Daya Manusia Indonesia. Jakarta. PT Raja Grafindo Persada. 